\title{
Calculation of the CD Spectrum of Class A $\beta$-Lactamase from Escherichia coli (TEM-1)
}

\author{
C. Christov, S. Gabriel ${ }^{\mathrm{a}}$, B. Atanasov, and J. Fleischhauer ${ }^{\mathrm{a}}$ \\ Institute of Organic Chemistry, BAS, 1113-Sofia, Bulgaria \\ ${ }^{\text {a }}$ Institute of Organic Chemistry, Rheinisch-Westfälische Technische Hochschule, D-52072 Aachen \\ Reprint requests to Prof. J. F.; Fax: +49 2418888 385; \\ E-mail: Joerg.Fleischhauer@thc.rwth-aachen.de
}

Z. Naturforsch. 56 a, 757-760 (2001); received September 12, 2001

The Circular Dichroism (CD) spectrum of $\beta$-lactamase from Escherichia coli (TEM-1) has been calculated with the matrix method on the basis of the x-ray diffraction structure. All known transitions in the peptide and side-chain groups, especially the aromatic and disulfide groups have been included. The calculations were performed with and without the tryptophan (Trp) residues. Rotational strengths calculated with the matrix method were combined with Gaussians to generate the $\mathrm{CD}$ spectrum. The calculated spectrum reproduces the signs and approximate magnitudes of the $\mathrm{CD}$ bands rather well only when the trytophan side chains are included. However, the experimental negative double band at 208 and $222 \mathrm{~nm}$, which is characteristic for $\alpha$-helices, is absent in the calculated spectrum.

Key words: $\beta$-Lactamase; CD-spectrum; Matrix Method.

\section{Introduction}

$\beta$-lactamases are enzymes which are produced by pathogenic microorganisms which catalyze the hydrolysis of $\beta$-lactam antibiotics and are the major reason for bacterial resistance. A large number of this type of enzyme has been studied, and four classes (A, $\mathrm{B}, \mathrm{C}$ and D) are recognized on the basis of their primary structures and substrate specificities $[1,2]$. The classes $\mathrm{A}, \mathrm{C}$, and $\mathrm{D}$ are unique serine proteases.

We wanted to calculate the CD-spectrum of a class A $\beta$-lactamase (isolated from E.-coli, TEM-1, EC 3.5.2.6, relative molecular mass: $28907 \mathrm{Da}$ ). For this enzyme the crystal structure [3] and the CD-spectrum [4] are known. For the calculation we used the socalled matrix method [5] with modifications by Goux and Hooker [6]. This method is implemented in our program MATMAC [7] and had been successfully applied to the calculation of the CD-spectra of other proteins [8].

\section{Materials and Methods}

For the calculations we took the coordinates of the $\mathrm{x}$-ray structure (see Fig. 1) of the $\beta$-lactamase TEM-1 at $1.8 \AA$ resolution from the Protein Data Bank (File: 1btl.pdb) [9]. For this protein 1047 basis functions were incorporated. Each of these functions is a product of 353 group wave functions, of which 352 are ground states and one is an excited state. Functions with two or more excited groups were not taken into account. In order to set up the matrix of the hamiltonian, the positions and charges of the monopoles for the different groups are needed. For all the groups besides Trp we used the parameters from [8]. For the Trp side chain we took the indole molecule as the model chromophore and performed an INDO/2S-CI calculation [11] with only singly excited configurations with the programs DZDO and MCD3SP [12]. We took into account transitions from the 13 highest occupied into the 13 lowest unoccupied molecular orbitals. From the transition and permanent electric densities the monopoles for indole were then calculated with the numerical procedure described in $[13,8]$. The parameters used for indole are collected in Table 1. The orientation of the calculated electric transition moments (see Fig. 2) are in qualitative agreement with the experimentally determined moments [14]. For the transition energies experimental values were used [14]. 


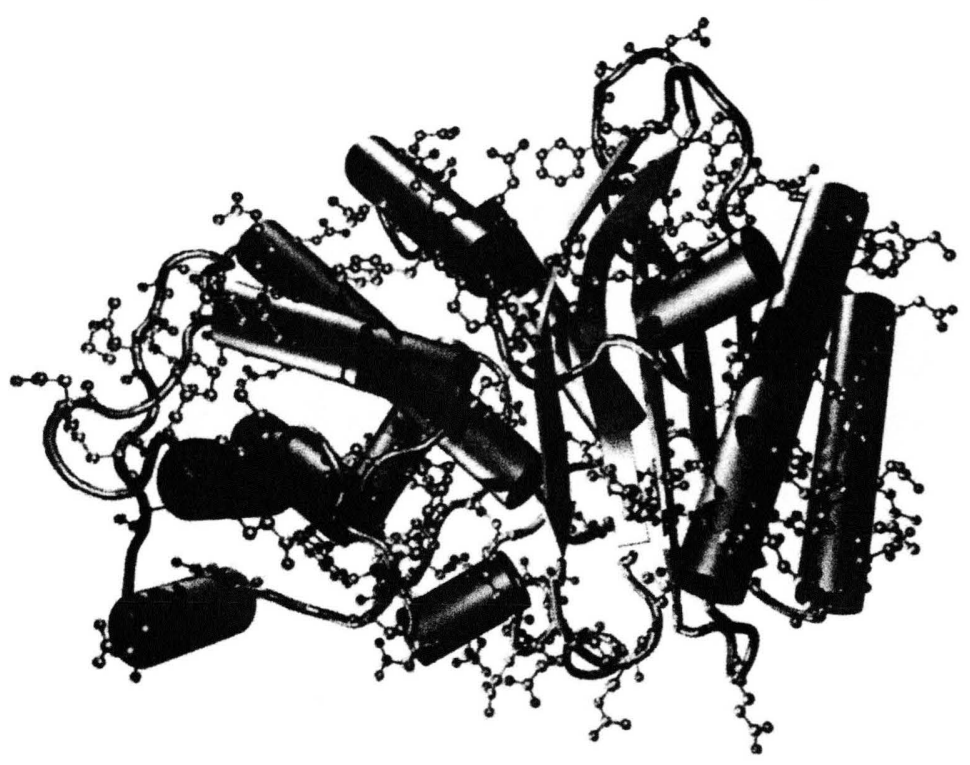

Fig. 1. Structure of the TEM- $1 \beta$-lactamase. Helical regions are drawn as cylinders and beta-sheets as arrows. Random coil regions are symbolized as tubes. The side chains which were used in the calculation are drawn as sticks and balls. The figure was created with the program VMD [10].
Table 1. Experimental transition energies [14], calculated electric transition moments and oscillator strengths, and experimental oscillator strength [15] of indole.

\begin{tabular}{ccrrcc}
\hline Transition & Energy [cm $\left.{ }^{-1}\right]$ & $\mu_{x}[\mathrm{D}]$ & $\mu_{y}$ [D] & $f_{\text {calc. }}$ & $f_{\text {exp. }}[15]$ \\
\hline $\mathrm{L}_{b}$ & 34423 & -0.496 & -0.599 & 0.01 & 0.01 \\
$\mathrm{~L}_{a}$ & 35842 & 3.151 & -1.310 & 0.19 & 0.12 \\
$\mathrm{~B}_{b}$ & 45045 & 4.560 & 3.300 & 0.60 & 0.68 \\
$\mathrm{~B}_{a}$ & 50000 & 3.890 & -1.746 & 0.38 & - \\
\hline
\end{tabular}

To generate the CD-spectrum, the calculated rotational strengths were combined with Gaussian band shape functions. Except for the disulfide transitions, the half bandwidths used were $16.8 \mathrm{~nm}$ in the spectral range between 300 and $250 \mathrm{~nm}, 14.1 \mathrm{~nm}$ between 250 and $157 \mathrm{~nm}$, and $9.2 \mathrm{~nm}$ below $157 \mathrm{~nm}$. For the disulfide we used a halfbandwidth of $30 \mathrm{~nm}$ for the long-wavelength transition and $15 \mathrm{~nm}$ for the shortwavelength component [8].

\section{Results and Discussion}

\subsection{The Near UV CD-spectra}

The experimental and calculated CD-spectra of $\beta$ lactamase in the near UV are shown in Figure 3. The experimental CD-spectrum exhibits a negative band in the region between $240-300 \mathrm{~nm}$. The calculated CD-spectrum without the Trp residues shows a positive band in this region, whereas the calculation with the tryptophans is in better agreement with the experi-

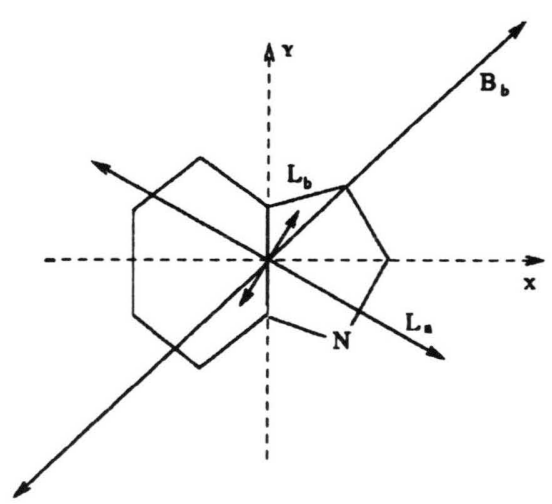

Fig. 2. Calculated electric transition moments.

ment. From the analysis of the matrix method results in Table 2 it can be seen that the main contribution to this negative band originates from an $\mathrm{L}_{a}$ transition in the $\operatorname{Trp}(210)$ residue.

\subsection{The Far UV CD-spectrum}

The CD in the far UV (see Fig. 4) is a reflection mainly of the secondary structure of the protein [16]. The spectrum can be decomposed into at least three bands: two negative bands at 208 and $222 \mathrm{~nm}$ and a positive one near $190 \mathrm{~nm}$. This set of three bands is characteristic of the $\alpha$-helix. The $222 \mathrm{~nm}$ band is theoretically assigned to the $n \pi^{*}$ transition of the peptide chromophores, while the other two bands result from exciton splitting of the $\pi \pi^{*}$ transition of peptide 


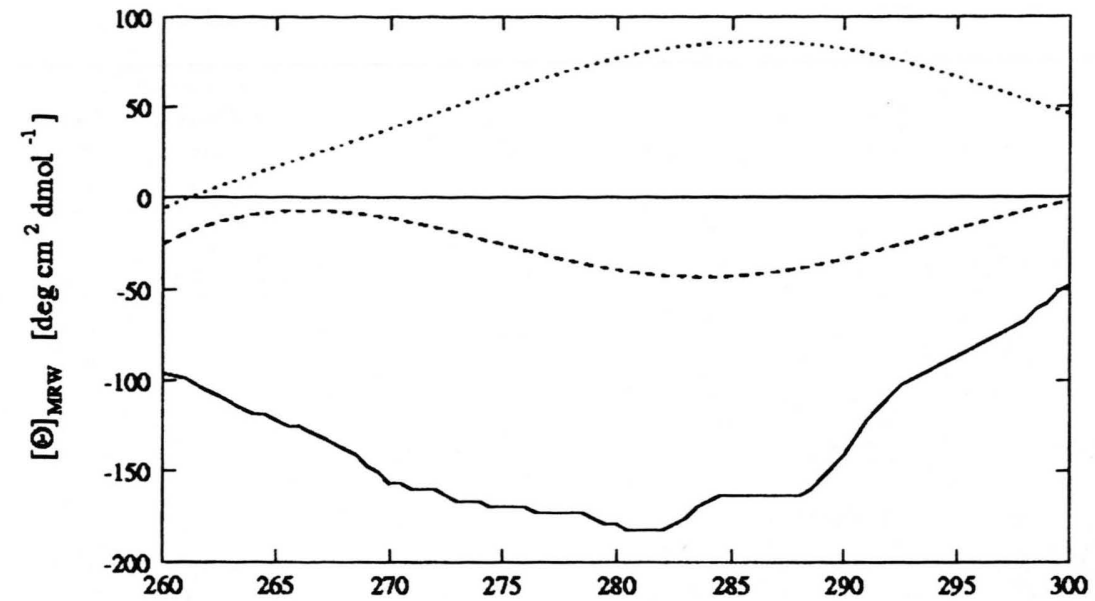

$\lambda[\mathrm{nm}]$

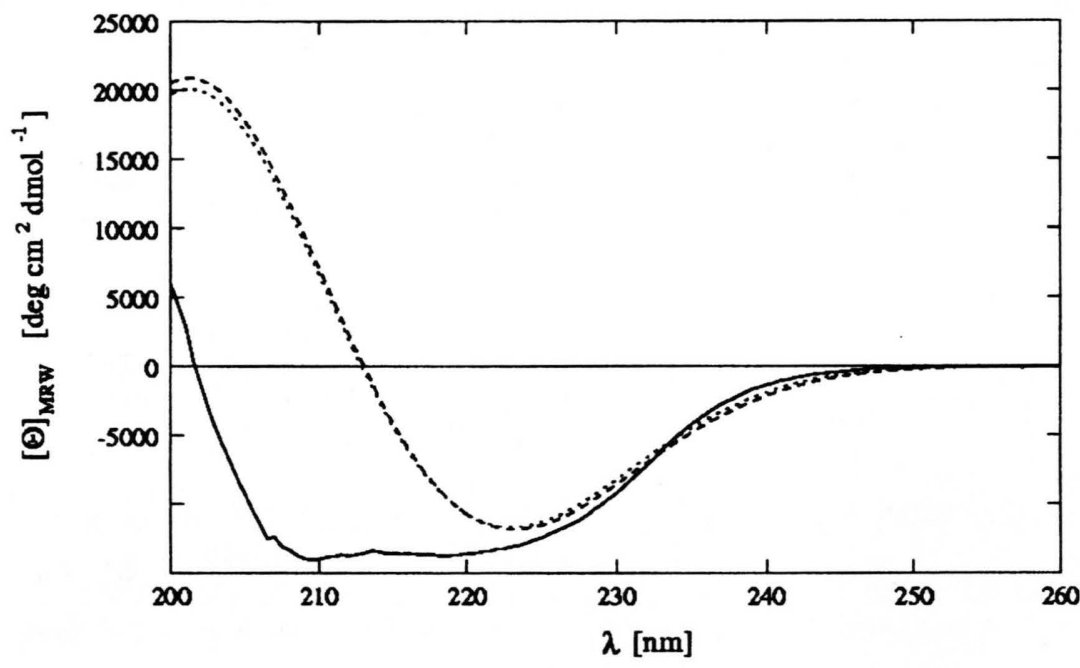

Fig. 3. Experimental and calculated near UV CD spectra of $\beta$ Lactamase; ...: calculated without Trp, -- -: calculated with Trp, -: experimental.

Fig. 4. Experimental and calculated far UV CD spectra of $\beta$ Lactamase; .... : calculated without $\operatorname{Trp},---$ : calculated with $\operatorname{Trp}$, -: experimental.

groups in helices, the $208 \mathrm{~nm}$ band with transitions parallel to the helix axis and the $190 \mathrm{~nm}$ band with transition moments perpendicular to the axis. This splitting is not shown in the calculated spectrum. The absence of the negative $208 \mathrm{~nm}$ band from the calculated far-UV CD spectrum was also observed in the calculation for RNase A by Kurapkat et al. [8]. They attributed the failure to reproduce this feature of the $\alpha$-helix CD spectrum to the short length of the helices in RNase A. The average helix length in $\beta$-lactamase is substantially larger than in RNase, so this explanation is not likely. A more plausible explanation is that the transition moment direction for the amide NV1 transition used in [8] and in the present calculation is smaller than the experimental value $[17,18]$.
The negative band between 220 and $230 \mathrm{~nm}$ mainly stems from $B_{b}$ transitions in the residues TRP(229), $\operatorname{TRP}(290)$ and TRP(210) (see Table 2) and from $n \pi^{*}$ transitions in the peptide backbone.

\section{Acknowledgements}

The authors wish to thank Prof. R. W. Woody for helpfull discussions and Dr. M. Vanhove, who kindly provided us with the numerical CD-data of TEM- 1. This work was supported by Grant Fl 142/3-3 from the Deutsche Forschungsgemeinschaft to J. F., DAAD scholarship support to C.C., and Bulgarian Science Foundation projects X-823 to B. A., MU-X-1001 to C. C. 
Table 2. Analysis of the Matrix Method Result for TEM-1 $\beta$-Lactamase. The numbering of the residues is the same as in the pdb file 1 btl.pdb [9].

\begin{tabular}{|c|c|c|c|c|c|}
\hline Tran & tion & $\begin{array}{l}\text { Local } \\
\text { Group }\end{array}$ & & $\begin{array}{c}\text { Transition } \\
\text { Wavelength }\end{array}$ & $\begin{array}{l}\text { Rotional } \\
\text { Strength }\end{array}$ \\
\hline 1 & $\mathrm{~L}_{\mathrm{b}}$ & $\operatorname{TRP}(210)$ & 95.17 & 295.6 & +0.001 \\
\hline 1 & $\mathrm{~B}_{\mathrm{b}}$ & $\operatorname{TRP}(210)$ & 4.43 & 295.0 & +0.001 \\
\hline & $\mathrm{L}_{\mathrm{b}}$ & TRP(290) & 87.66 & & \\
\hline 2 & $\mathrm{~L}_{\mathrm{a}}$ & $\operatorname{TRP}(290)$ & 9.31 & 295.0 & +0.010 \\
\hline & $\mathrm{B}_{\mathrm{b}}$ & $\operatorname{TRP}(290)$ & 2.88 & & \\
\hline 3 & $\mathrm{~L}_{\mathrm{b}}$ & TRP(165) & 95.40 & 292.0 & +0.012 \\
\hline 3 & $\mathrm{~L}_{\mathrm{a}}$ & $\operatorname{TRP}(165)$ & 3.78 & & \\
\hline 4 & $\mathrm{~L}_{\mathrm{b}}$ & TRP(229) & 99.83 & 290.6 & +0.001 \\
\hline 5 & $\mathrm{n}_{1} \sigma^{*}$ & Cys(77)-Cys(123) & 74.46 & 2881 & +0.064 \\
\hline & $\mathrm{n}_{4} \sigma^{*}$ & Cys(77)-Cys(123) & 24.88 & 288.1 & +0.004 \\
\hline 6 & $\mathrm{~L}_{\mathrm{a}}$ & $\operatorname{TRP}(210)$ & 97.82 & 280.4 & -0.376 \\
\hline & $\mathrm{L}_{\mathrm{a}}$ & TRP(229) & 84.40 & & \\
\hline 7 & $\mathrm{~L}_{\mathrm{b}}$ & $\operatorname{TRP}(290)$ & 2.14 & 279.5 & +0.055 \\
\hline & $\mathrm{L}_{\mathrm{a}}$ & $\operatorname{TRP}(290)$ & 13.14 & & \\
\hline 8 & $\mathrm{~L}_{\mathrm{b}}$ & TRP(165) & 3.61 & 278.9 & -0.123 \\
\hline 0 & $\mathrm{~L}_{\mathrm{a}}$ & $\operatorname{TRP}(165)$ & 95.90 & 210.9 & -0.123 \\
\hline & $\mathrm{L}_{\mathrm{b}}$ & TRP(229) & 15.13 & & \\
\hline 9 & $\mathrm{~L}_{\mathrm{a}}$ & TRP(290) & 7.22 & 277.7 & +0.131 \\
\hline & $\mathrm{L}_{\mathrm{b}}$ & $\operatorname{TRP}(290)$ & 76.64 & & \\
\hline 10 & $\mathrm{~L}_{\mathrm{b}}$ & TYR(264) & 99.17 & 277.4 & -0.005 \\
\hline 11 & $\mathrm{~L}_{\mathrm{b}}$ & TYR(97) & 4.10 & 2773 & +0021 \\
\hline & $\mathrm{L}_{\mathrm{b}}$ & TYR(105) & 95.09 & 271.3 & +0.021 \\
\hline 12 & $\mathrm{~L}_{\mathrm{b}}$ & TYR(97) & 95.66 & 277.2 & +0087 \\
\hline 12 & $\mathrm{~L}_{\mathrm{b}}$ & TYR(105) & 4.10 & 211.2 & \\
\hline 13 & $\mathrm{~L}_{\mathrm{b}}$ & TYR(46) & 99.06 & 277.2 & +0.090 \\
\hline 14 & $\mathrm{~L}_{b}$ & PHE(230) & 99.30 & 260.7 & +0.010 \\
\hline 15 & $\mathrm{~L}_{\mathrm{b}}$ & PHE(72) & 99.31 & 260.7 & -0.010 \\
\hline
\end{tabular}

\begin{tabular}{|c|c|c|c|c|}
\hline Transition & $\begin{array}{l}\text { Local } \\
\text { Group } \\
\text { Character }\end{array}$ & $\%$ & $\begin{array}{l}\text { Transition } \\
\text { Wavelength } \\
\quad(\mathrm{nm})\end{array}$ & $\begin{array}{l}\text { Rotional } \\
\text { Strength } \\
\text { (DBM) }\end{array}$ \\
\hline $16 \mathrm{~L}_{\mathrm{b}}$ & $\operatorname{PHE}(60)$ & 99.51 & 260.5 & +0.001 \\
\hline $17 \mathrm{~L}_{\mathrm{b}}$ & PHE(151) & 99.89 & 260.1 & -0.0003 \\
\hline $18 \quad \mathrm{~L}_{\mathrm{b}}$ & PHE $(66)$ & 99.93 & 260.1 & +0.002 \\
\hline $19 \begin{array}{l}\mathrm{n}_{1} \sigma^{*} \\
\mathrm{n}_{4} \sigma^{*}\end{array}$ & $\begin{array}{l}\text { Cys(77)-Cys(123) } \\
\text { Cys(77)-Cys(123) }\end{array}$ & $\begin{array}{l}25.07 \\
74.74\end{array}$ & 243.8 & +0.204 \\
\hline $20 \begin{array}{l}n_{1} \pi^{*} \\
n_{2} \pi^{*}\end{array}$ & $\begin{array}{l}\text { ASP }(157) \\
\operatorname{ASP}(157)\end{array}$ & $\begin{array}{l}0.50 \\
0.50\end{array}$ & 230.9 & -0.002 \\
\hline $21 \mathrm{NV}_{2}$ & $\begin{array}{c}\text { Pep(LEU(102)-VAL(103)) } \\
\text { Pep(LEU(102)-VAL(103)) } \\
\text { TYR(105) }\end{array}$ & $\begin{array}{c}39.65 \\
2.45 \\
57.27\end{array}$ & 228.2 & 0.044 \\
\hline $22 \mathrm{~L}_{a}$ & TYR(97) & 98.48 & 227.4 & 0.233 \\
\hline $23 \begin{array}{l}\mathrm{L}_{a} \\
\mathrm{~L}_{a}\end{array}$ & $\begin{array}{c}\text { TYR(46) } \\
\text { TYR(264) }\end{array}$ & $\begin{array}{l}76.81 \\
21.82 \\
\end{array}$ & 227.3 & 1.780 \\
\hline $24 \begin{array}{l}\mathrm{L}_{a} \\
\mathrm{~L}_{a}\end{array}$ & $\begin{array}{c}\text { TYR(46) } \\
\text { TYR }(264) \\
\end{array}$ & $\begin{array}{l}21.56 \\
77.62 \\
\end{array}$ & 227.1 & -1.400 \\
\hline $\begin{array}{c}n \pi^{*} \\
25 \mathrm{NV}_{2} \\
\mathrm{~L}_{a}\end{array}$ & $\begin{array}{c}\text { Pep(LEU(102)-VAL(103)) } \\
\text { Pep(LEU(102)-VAL(103)) } \\
\text { TYR(105) }\end{array}$ & $\begin{array}{c}55.05 \\
2.49 \\
41.83\end{array}$ & 226.1 & 0.269 \\
\hline $26 \begin{array}{cc}n \pi^{*} \\
& \mathrm{~B}_{b} \\
\mathrm{~L}_{b} \\
& \mathrm{~B}_{b} \\
& \mathrm{~B}_{a}\end{array}$ & $\begin{array}{l}\operatorname{PRO}(252) \\
\operatorname{TRP}(229) \\
\operatorname{TRP}(290) \\
\operatorname{TRP}(290) \\
\operatorname{TRP}(290)\end{array}$ & $\begin{array}{c}1.20 \\
54.04 \\
1.16 \\
39.16 \\
2.08\end{array}$ & 225.9 & -2.512 \\
\hline $27 \begin{array}{c}n \pi^{*} \\
\mathrm{~L}_{b} \\
\\
\mathrm{~B}_{b}\end{array}$ & $\begin{array}{l}\text { GLN(206) } \\
\operatorname{TRP}(210) \\
\operatorname{TRP}(210)\end{array}$ & $\begin{array}{c}1.90 \\
2.79 \\
76.51\end{array}$ & 224.6 & -0.826 \\
\hline
\end{tabular}

[1] R. Ambler, Phil. Trans. Roy. Soc. London B 289, 321 (1980).

[2] S. Waley in: "The Chemistry of $\beta$-lactams", edited by M. Page, Glasgow: Blackie Academic \& professional 1992, 198.

[3] C. Jelsch, L. Moury, J.-M. Masson, and J.-P. Samama, Proteins: Struct. Funct. Genet. 16, 364 (1993).

[4] M. Vanhove, X. Raquet, and J.-M. Frere, Proteins: Struct. Funct. Genet. 22, 110 (1995).

[5] P. M. Bayley, E. B. Nielsen, and J.A. Schellman, J. Phys. Chem. 73, 228 (1969).

[6] W. J. Goux and T. M. Hooker Jr., J. Amer. Chem. Soc. 102, 7080 (1980).

[7] MATMAC V2.0 (1991) Matrix and Tinoco Method Program for the calculation of Rotationalstrength of Biopolymers, developed by J. Fleischhauer, B. Kramer, E. Zobel, A. Koslowski, RWTH Aachen.

[8] G. Kurapkat, P. Krüger, A. Wollmer, J. Fleischhauer, B. Kramer, E. Zobel, A. Koslowski, H. Botterweck, and R. W. Woody, Biopolymers 41, 267 (1997).

[9] F. Bernstein, T. Koetzle, G. Williams, E. Meyer,

M. Brice, J. Rodgers, O. Kenard, T. Shimanouchi, and M. Tasumi, J. Mol. Biol. 112, 535 (1997).

[10] W. Humphrey, A. Dalke, and K. Schulten, 'VMD - Visual Molecular Dynamics', J. Molec. Graphics 1996, 14.1, 33-38.

[11] J. A. Pople, D. Beveridge, and P. Dobosh, J. Chem. Phys. 47, 2026 (1967).

[12] The programs DZDO and MCD3SP were written by J. Downing and J. Michl, University of Colorado, Boulder, USA.

[13] B. Kramer, Ph. D. thesis, RWTH Aachen (1991).

[14] B. Albinson and B. Nordén, J. Phys. Chem. 96, 6204 (1992).

[15] Y. Yamamoto and J. Tanaka; Bul. Chem. Soc. Japan 45, 1362 (1972).

[16] R. W. Woody in: "Circular Dichroism and the Conformational Analysis of Biomolecules", edited by G. Fasman, Plenum Press, New York 1996, p. 25.

[17] L. B. Clark, J. Amer. Chem. Soc. 117, 7974 (1995).

[18] R. W. Woody and N. Sreerama, J.Chem.Phys. 111, 2844 (1999). 